\title{
DIDELIO MEISTRIŠKUMO BAIDARININKŲ OLIMPINIŲ NUOTOLIŲ İVIKIMO RODIKLIUS LEMIANTYS VEIKSNIAI
}

\author{
Egidijus Balčiūnas, Juozas Skernevičius, Kazys Milašius
}

Vilniaus pedagoginis universitetas, Vilnius, Lietuva

Egidijus Balčiūnas. Socialinių mokslų magistras. Vilniaus pedagoginio universiteto Sporto pedagogikos katedros doktorantas. Mokslinių tyrimų kryptys: didelio meistriškumo baidarininkų organizmo adaptacija prie fizinių krūvių; sportininkų fizinių ir funkcinių galių tyrimas.

\section{SANTRAUKA}

Tyrimo tikslas - ištirti didelio meistriškumo baidarininku 500 ir 1000 m nuotoliu irklavimo sportinio rezultato sqsaja su ju fizinio išsivystymo, fiziniu galiu, ¿vairios trukmès darbo galingumo, kraujotakos sistemos funkciniais rodikliais.

2008 m. parengiamojo laikotarpio pabaigoje pagal programa „,Londonas-2012“ buvo ištirti 8 Lietuvos baidariu irklavimo olimpinès rinktinès kandidatai. Išmatuoti ju pagrindiniai fizinio išsivystymo rodikliai: ügis, kūno masè, riebalu masè, raumenu masè, dešinès ir kairès plaštakos jèga, gyvybinis plaučiu tūris (Dadelienè, 2008). Tiriant fizini parengtumq išmatuotas šuolio aukštis tiriamajam atsispiriant abiem kojom ir mojant rankomis, absoliutus ir santykinis vienkartinio raumenu susitraukimo galingumas (VRSG) (Bosco et al., 1983), anaerobinis alaktatinis raumenu galingumas (AARG) (laiptine ergometrija). Specialusis anaerobinis alaktatinis galingumas nustatytas dirbant baidariu ergometru 10 s. 500 ir 1000 m simuliacinis testas atliktas tuo pačiu baidariu ergometru individualiai taikant specialia programa pagal sportininko kūno masę. Kraujotakos sistemos funkciniam pajègumui vertinti nustatytas pulso dažnis (PD) tv. I min tiriamajam gulint ir Rufje indeksas (RI) (Weppep, 1973), hemoglobino (Hb) koncentracija kraujyje.

Atliekant tyrimo duomenu analizę pasitelkti matematinès statistikos metodai. Ryšiams tarp rodikliu ìvertinti taikytas tiesinès koreliacijos (Pirsono) koeficiento skaičiavimo metodas (Gonestas, Strielčiūnas, 2003).

Tyrimas parodè, kad didelio meistriškumo sportininku 500 m nuotolio ¿̨veikimo rodikliai turi sqsaju su kūno ir raumenu masès rodikliais, su 1000 m nuotolio ¿̇veikimo laiku ryšys silpnesnis.

10 s trukmés specialusis (tiek absoliutus, tiek santykinis) darbo galingumas labai stipriai koreliuoja su 500 m jveikimo laiku, o su 1000 m Ł̨veikimo laiku ryšys yra silpnesnis, tačiau statistiškai patikimas ( $p<0,05)$.

Didelio meistriškumo baidarininku kraujotakos rodikliai: RI, PD ramybès būsenoje, Hb koncentracija kraujyje neturejjo patikimo ryšio nei su 500 m, nei su 1000 m nuotolio įveikimo laiku.

Raktažodžiai: baidarininku fizinis išsivystymas, fizinis parengtumas, kraujotaka, rodikliu koreliaciniai ryšiai.

\section{IVADAS}

$\mathrm{L}$ ietuvos baidarininkai, iveikdami $500 \mathrm{~m}$ nuotoli, pastarajame dešimtmetyje pasiekè puikių rezultatu ivairiausiose pasaulio ir Europos varžybose (prizinès vietos pasaulio ir Europos čempionatuose, 7 vieta Sidnejjaus olimpinėse žaidynèse, 7 vieta Atènuose, 11 vieta Pekine). $500 \mathrm{~m}$ nuotolis iveikiamas per $1 \mathrm{~min}$
$35-45 \mathrm{~s}$. Tokios trukmès intensyvaus darbo metu raumenyse vyrauja anaerobinès glikolizès reakcijos (Willmore, Costill, 1994; Astrand, Rohdahl, 1997; Skernevičius, 1997; Dadelienè, 2008). Iveikiant $1000 \mathrm{~m}$ nuotoli, raumenyse vyrauja aerobinès energijos gamybos reakcijos (70-80\%) (Лисенко и др., 2004). Startinio grei- 
tẻjimo metu raumenyse vyrauja ATP resintezè iš kreatinfosfato (KP). Toliau šitaip dirbant vis daugiau organizme vyksta glikolitinių reakcijų. Šiu reakcijų didžiausias intensyvumas pasiekiamas per 60 s (Byrnes, Kearney, 1997). Darbo metu gaminama daug pieno rūgšties, kuri, patekusi i kraują, kinta virsdama laktatu (La). La koncentracija kraujyje gali padidèti iki $20 \mathrm{mmol} / \mathrm{l}$, tačiau $1000 \mathrm{~m}$ nuotolio pabaigoje pradejo vyrauti aerobinès energijos gamybos reakcijos. Taigi baidarininkų $1000 \mathrm{~m}$ nuotolio sportinį rezultatą lemia daugelis veiksnių, tačiau jų sąsaja dar nèra pakankamai išnagrinèta. Tirti fizinio išsivystymo, parengtumo, funkcinio pajègumo rodikliu ryšiai su 200, $500 \mathrm{~m}$ specialiuoju parengtumu (Balčiūnas ir kt., 2007; Balčiūnas, 2009), tačiau šių rodiklių sąsają su $1000 \mathrm{~m}$ olimpinès rungties rodikliais nenagrinèta. Tai mokslinè problema, kurią norint išspręsti tenka pasitelkti edukologijos, fiziologijos, biochemijos ir kitu mokslu tyrimu metodologiją.

Darome hipotetinę prielaidą, kad baidarininku 500 ir 1000 m nuotoliu iveikimo sportinis rezultatas turi sąsają su jų fizinio išsivystymo pagrindiniais rodikliais, ypač su raumenu masès išvystymu, raumenu galingumu, atliekant įvairios trukmès darbą, su kraujotakos sistemos funkciniu pajègumu.

Tyrimo objektas - Lietuvos didelio meistriškumo baidarininku 500 ir 1000 m nuotoliu ivveikimo rodiklių sąsaja su fizinio išsivystymo, raumenų galingumo, atliekant i̇vairios trukmès darbą, su kraujotakos sistemos funkciniais rodikliais.

Tyrimo tikslas - ištirti didelio meistriškumo baidarininku 500 ir $1000 \mathrm{~m}$ nuotolių irklavimo sportinio rezultato sąsają su jų fizinio išsivystymo, fizinių galių, ivvairios trukmès darbo galingumo, kraujotakos sistemos funkcinio pajègumo rodikliais.

\section{Uždaviniai:}

1. Nustatyti baidarininkų pagrindinių fizinio išsivystymo rodiklių sąsają su 500 ir $1000 \mathrm{~m}$ nuotoliu iveikimo rodikliais, taip pat su kitais specialiojo parengtumo rodikliais.

2. Išsiaiškinti, koks ryšys tarp raumenų galingumo, atliekant įvairios trukmès darbą, ir 500 bei $1000 \mathrm{~m}$ nuotoliu iveikimo rezultato, specialiojo pajègumo.

3. Ištirti, koks kraujotakos funkcinio pajègumo rodikliu ir baidarininku 500 ir 1000 m nuotoliu ivveikimo rezultatų ryšys.

\section{TYRIMO ORGANIZAVIMAS IR METODAI}

$2008 \mathrm{~m}$. parengiamojo laikotarpio pabaigoje pagal programą „Londonas-2012“ ištirti 8 Lietuvos olimpinès rinktinès kandidatai ir olimpinio rezervo baidarininkai, kuriu amžiaus vidurkis $24,6 \pm 1,4$ m., ūgio $-184,2 \pm 3,4 \mathrm{~cm}$, kūno masès $-79,93 \pm 1,90 \mathrm{~kg}$.

Išmatuoti pagrindiniai baidarininkų fizinio išsivystymo rodikliai: ūgis, kūno masè, riebalų masè, raumenų masè, dešinès ir kairès plaštakos jèga, gyvybinis plaučių tūris (GPT) (Dadelienè, 2008). Tiriant fizini parengtumą išmatuotas šuolio aukštis tiriamajam atsispiriant abiem kojom ir mojant rankomis, absoliutus ir santykinis vienkartinio raumenų susitraukimo galingumas (VRSG) (Bosco et al., 1983), anaerobinis alaktatinis raumenu galingumas (AARG) (laiptine ergometrija). Specialusis anaerobinis alaktatinis galingumas nustatytas tiriamajam dirbant baidarių ergometru („Dansprint“", Danija) didžiausiomis pastangomis $10 \mathrm{~s}$ (Raslanas, Skernevičius, 1998). 500 ir $1000 \mathrm{~m}$ nuotoliu iveikimo simuliacinis testas atliktas tuo pačiu baidariu ergometru individualiai taikant specialią programą pagal sportininko kūno masę, fiksuojant nuotolio íveikimo laiką. Kraujotakos sistemos funkcini pajègumą vertinome pagal pulso dažnị (PD) tiriamajam gulint (tv. / min) ir Rufjè indeksą (RI) (Шeppep, 1973), nustatėme hemoglobino $(\mathrm{Hb})$ koncentraciją kraujyje.

Tyrimo duomenu analizei atlikti pasitelkème matematinès statistikos metodus. Skaičiavome aritmetinius vidurkius $(\overline{\mathrm{X}})$ ir ju reprezentacines paklaidas $(S \bar{x})$, standartinius nuokrypius $(S)$ ir ju variacijos koeficientus (V). Sklaidos plotui įvertinti pateikème didžiausias ir mažiausias rodikliu reikšmes. Ryšiai tarp rodikliu vertinti Pirsono tiesinès koreliacijos koeficiento skaičiavimo metodu. Ryšio patikimumui įvertinti taikème tris lygmenis $(r=0,61-0,80, p<0,05 ; r=0,81-0,90$, $\mathrm{p}<0,01, \mathrm{r}=0,91$ ir daugiau, $\mathrm{p}<0,001$ ) (Gonestas, Strielčiūnas, 2003). Sudarème duomenų porų koreliacinius laukus, taip pat skaičiavome regresijos koeficientus.

\section{REZULTATAI}

Tyrimo duomenys rodo (1 lent.) įvairią rodiklių sklaidą. Pagrindinių rodiklių -500 ir $1000 \mathrm{~m}$ nuotolių ivveikimo rezultatu — sklaida labai maža, ji sudarè tik 3,60 ir 4,89\%. Pagrindinių fizinio išsivystymo rodiklių (ūgio, kūno masès) — taip 
1 lentelè. Lietuvos didelio meistriškumo baidarininkų tyrimo statistiniai rodikliai

\begin{tabular}{|c|c|c|c|c|c|c|c|c|c|c|c|c|c|c|c|}
\hline \multirow{2}{*}{$\begin{array}{c}\text { Baidarininko } \\
\text { inicialai }\end{array}$} & \multirow{2}{*}{\begin{tabular}{|c|} 
Šuolio \\
aukštis, \\
cm
\end{tabular}} & \multicolumn{2}{|c|}{ VRSG } & \multicolumn{2}{|c|}{ AARG } & \multicolumn{2}{|c|}{$10 \mathrm{~s}$} & \multirow{2}{*}{$\begin{array}{c}\text { Kūno } \\
\text { masé, } \\
\text { kg }\end{array}$} & \multirow{2}{*}{$\begin{array}{c}\text { Raumenų } \\
\text { masé, } \mathbf{k g}\end{array}$} & \multirow{2}{*}{$\begin{array}{c}\text { Parank. } \\
\text { rank. jèga, } \\
\text { kg }\end{array}$} & \multirow{2}{*}{$\begin{array}{l}\text { PD ramybès } \\
\text { būsenoje, } \\
\text { tv. / min }\end{array}$} & \multirow{2}{*}{ RI } & \multirow{2}{*}{$\mathrm{Hb}, \mathrm{g} / \mathrm{I}$} & \multirow{2}{*}{$500 \mathrm{~m}, \mathrm{~s}$} & \multirow{2}{*}{$1000 \mathrm{~m}, \mathrm{~s}$} \\
\hline & & W & $\mathrm{W} / \mathrm{kg}$ & W & $\mathrm{W} / \mathrm{kg}$ & $\mathbf{W}$ & $\mathrm{W} / \mathbf{k g}$ & & & & & & & & \\
\hline E.B. & 50 & 2084 & 23,80 & 1510 & 17,2 & 890 & 10,17 & 87,9 & 50,1 & 72 & 60 & 5,2 & 160 & 102,4 & 232 \\
\hline R. P. & 54 & 2127 & 27,80 & 1228 & 16,1 & 746 & 9,80 & 76,4 & 42,6 & 46 & 65 & 2 & 170 & 107 & 238 \\
\hline J.V. & 56 & 2410 & 28,50 & 1582 & 18,7 & 747 & 8,80 & 84,5 & 49,0 & 54 & 70 & 7,2 & 151 & 108,1 & 244,5 \\
\hline I. N. & 32 & 1863 & 23,43 & 1372 & 17,25 & 656 & 8,30 & 79,5 & 44,9 & 86 & 40 & $-0,4$ & 168 & 109 & 266,2 \\
\hline R. M. & 35 & 1511 & 16,90 & 1421 & 17,02 & 577 & 8,46 & 80,0 & 46,7 & 62 & 60 & 4 & 165 & 109,3 & 242,2 \\
\hline V.S. & 49 & 1684 & 20,29 & 1358 & 16,37 & 631 & 7,60 & 82,1 & 46,3 & 50 & 64 & 4,4 & 147 & 111,1 & 245,4 \\
\hline A.O. & 45 & 1393 & 19,91 & 1091 & 15,59 & 492 & 6,80 & 70,0 & 40,6 & 50 & 68 & 10,4 & 144 & 116 & 264,7 \\
\hline A.O. & 55 & 2372 & 30,03 & 1394 & 17,65 & 581 & 7,50 & 79,0 & 43,6 & 67 & 49 & 1,2 & 173 & 111,8 & 245,2 \\
\hline$\overline{\mathrm{X}}$ & 47,00 & 1930,50 & 23,83 & 1369,50 & 16,99 & 665,00 & 8,43 & 79,93 & 45,48 & 60,88 & 59,50 & 4,25 & 159,75 & 109,34 & 247,28 \\
\hline $\mathrm{S} \overline{\mathrm{x}}$ & 3,22 & 134,78 & 1,65 & 54,42 & 0,34 & 44,30 & 0,41 & 1,90 & 1,13 & 4,82 & 3,60 & 1,22 & 3,93 & 1,39 & 4,27 \\
\hline $\mathrm{S}$ & 9,10 & 381,21 & 4,66 & 153,94 & 0,97 & 125,29 & 1,15 & 5,36 & 3,20 & 13,62 & 10,17 & 3,45 & 11,11 & 3,94 & 12,09 \\
\hline $\mathrm{V}$ & 19,36 & 19,75 & 19,55 & 11,24 & 5,71 & 18,84 & 13,64 & 6,71 & 7,04 & 22,37 & 17,09 & 81,18 & 6,95 & 3,60 & 4,89 \\
\hline Min & 32,00 & 1393,00 & 16,90 & 1091,00 & 15,59 & 492,00 & 6,80 & 70,00 & 40,60 & 46,00 & 40,00 & $-0,40$ & 144,00 & 102,40 & 232,00 \\
\hline Max & 56,00 & 2410,00 & 30,03 & 1582,00 & 18,70 & 890,00 & 10,17 & 87,90 & 50,10 & 86,00 & 70,00 & 10,40 & 173,00 & 116,00 & 266,20 \\
\hline
\end{tabular}

Pastaba. VRSG — vienkartinio raumenų susitraukimo galingumas; AARG — anaerobinis alaktatinis raumenu galingumas;

$\mathrm{PD}$ - pulso dažnis; $\mathrm{Hb}$ - hemoglobinas.

2 lentelè. Didelio meistriškumo baidarininkų varžybų nuotolio įveikimo laiko ir fizinio bei funkcinio parengtumo rodiklių koreliaciniai ryšiai

\begin{tabular}{|c|c|c|c|c|c|c|c|c|c|c|c|c|c|c|c|}
\hline \multirow{3}{*}{ Nr. } & \multirow{2}{*}{$\begin{array}{c}\text { Šolio } \\
\text { aukštis, } \\
\text { cm }\end{array}$} & \multicolumn{2}{|c|}{ VRSG } & \multicolumn{2}{|c|}{ AARG } & \multicolumn{2}{|c|}{$10 \mathrm{~s}$} & \multirow{2}{*}{$\begin{array}{c}\text { Kūno } \\
\text { masė, kg }\end{array}$} & \multirow{2}{*}{$\begin{array}{l}\text { Raumenų } \\
\text { masė, kg }\end{array}$} & \multirow{2}{*}{$\begin{array}{l}\text { Parank. } \\
\text { plaštak. } \\
\text { jèga, kg }\end{array}$} & \multirow{2}{*}{$\begin{array}{c}\text { PD } \\
\text { ramybès } \\
\text { būsenoje, } \\
\text { tv. / min }\end{array}$} & \multirow{2}{*}{$\begin{array}{c}\text { Rufjè } \\
\text { indeksas }\end{array}$} & \multirow[b]{2}{*}{ Hb, g / I } & \multirow[b]{2}{*}{$500 \mathrm{~m}, \mathrm{~s}$} & \multirow[b]{2}{*}{$1000 \mathrm{~m}, \mathrm{~s}$} \\
\hline & & $\mathbf{W}$ & W / kg & $\mathbf{W}$ & W / kg & $\mathbf{W}$ & W / kg & & & & & & & & \\
\hline & 1 & 2 & 3 & 4 & 5 & 6 & 7 & 8 & 9 & 10 & 11 & 12 & 13 & 14 & 15 \\
\hline 1 & 1,000 & & & & & & & & & & & & & & \\
\hline 2 & 0,672 & 1,000 & & & & & & & & & & & & & \\
\hline 3 & 0,705 & 0,938 & 1,000 & & & & & & & & & & & & \\
\hline 4 & 0,145 & 0,578 & 0,269 & 1,000 & & & & & & & & & & & \\
\hline 5 & 0,200 & 0,711 & 0,502 & 0,892 & 1,000 & & & & & & & & & & \\
\hline 6 & 0,348 & 0,573 & 0,389 & 0,589 & 0,373 & 1,000 & & & & & & & & & \\
\hline 7 & 0,189 & 0,449 & 0,280 & 0,461 & 0,246 & 0,911 & 1,000 & & & & & & & & \\
\hline 8 & 0,184 & 0,497 & 0,184 & 0,919 & 0,671 & 0,766 & 0,603 & 1,000 & & & & & & & \\
\hline 9 & 0,077 & 0,345 & 0,012 & 0,918 & 0,666 & 0,700 & 0,563 & 0,960 & 1,000 & & & & & & \\
\hline 10 & $-0,546$ & 0,125 & 0,022 & 0,384 & 0,393 & 0,180 & 0,130 & 0,348 & 0,293 & 1,000 & & & & & \\
\hline 11 & 0,508 & $-0,111$ & $-0,118$ & $-0,107$ & $-0,195$ & 0,091 & 0,086 & $-0,063$ & 0,076 & $-0,870$ & 1,000 & & & & \\
\hline 12 & 0,227 & $-0,342$ & $-0,312$ & $-0,197$ & $-0,199$ & $-0,157$ & $-0,254$ & $-0,208$ & $-0,007$ & $-0,548$ & 0,791 & 1,000 & & & \\
\hline 13 & $-0,114$ & 0,424 & 0,412 & 0,157 & 0,225 & 0,172 & 0,383 & 0,094 & $-0,064$ & 0,486 & $-0,663$ & $-0,847$ & 1,000 & & \\
\hline 14 & $-0,131$ & $-0,476$ & $-0,245$ & $-0,641$ & $-0,387$ & $-0,944$ & $-0,954$ & $-0,792$ & $-0,738$ & $-0,316$ & 0,057 & 0,318 & $-0,367$ & 1,000 & \\
\hline 15 & $-0,537$ & $-0,449$ & $-0,244$ & $-0,501$ & $-0,238$ & $-0,653$ & $-0,697$ & $-0,629$ & $-0,566$ & 0,239 & $-0,346$ & 0,084 & $-0,237$ & 0,697 & 1,000 \\
\hline
\end{tabular}

Pastaba. VRSG — vienkartinis raumenų susitraukimo galingumas; AARG — anaerobinis alaktatinis raumenu galingumas;

$\mathrm{PD}$ - pulso dažnis; Hb - hemoglobinas.

pat maža (atitinkamai 6,70 ir 7,03\%). Vadinasi, tiriamieji savo fizinio išsivystymo ir specialiojo sportinio parengtumo rodikliais gana homogeniški, tačiau juc kraujotakos ir funkcinio pajègumo rodiklio (Rufje testo duomenys) - labai skirtingi $(\mathrm{V}=81,17 \%$, sklaidos plotas - nuo 0,40 iki 10,40 vienetu). Tai rodo, kad prie tokių fizinių krūvių baidarininkų kraujotakos sistema prisitaiko labai skirtingai.

Analizuojant interkoreliacinę skalę (2 lent.) matyti, kad 1000 m nuotolio iqveikimo laikas pati- kimai koreliuoja su specialiojo anaerobinio alaktatinio $10 \mathrm{~s}$ trukmès darbo absoliutaus ir santykinio galingumo rodikliais $(\mathrm{r}=-0,65$ ir $\mathrm{r}=-0,70)$. $1000 \mathrm{~m}$ nuotolio ivveikimo laiko ir $10 \mathrm{~s}$ specialiojo darbo absoliutaus galingumo rodikliu koreliacinis laukas (1 pav.) rodo atvirkštinę sąsają. Regresijos tiesė rodo, kiek padidejus specialiojo $10 \mathrm{~s}$ trukmès darbo galingumui turètú kisti 1000 m nuotolio iveikimo laikas (kiek sutrumpètų laikas). $10 \mathrm{~s}$ trukmès darbo absoliutaus bei santykinio galingumo ir $500 \mathrm{~m}$ nuotolio íveikimo laiko atvirkš- 


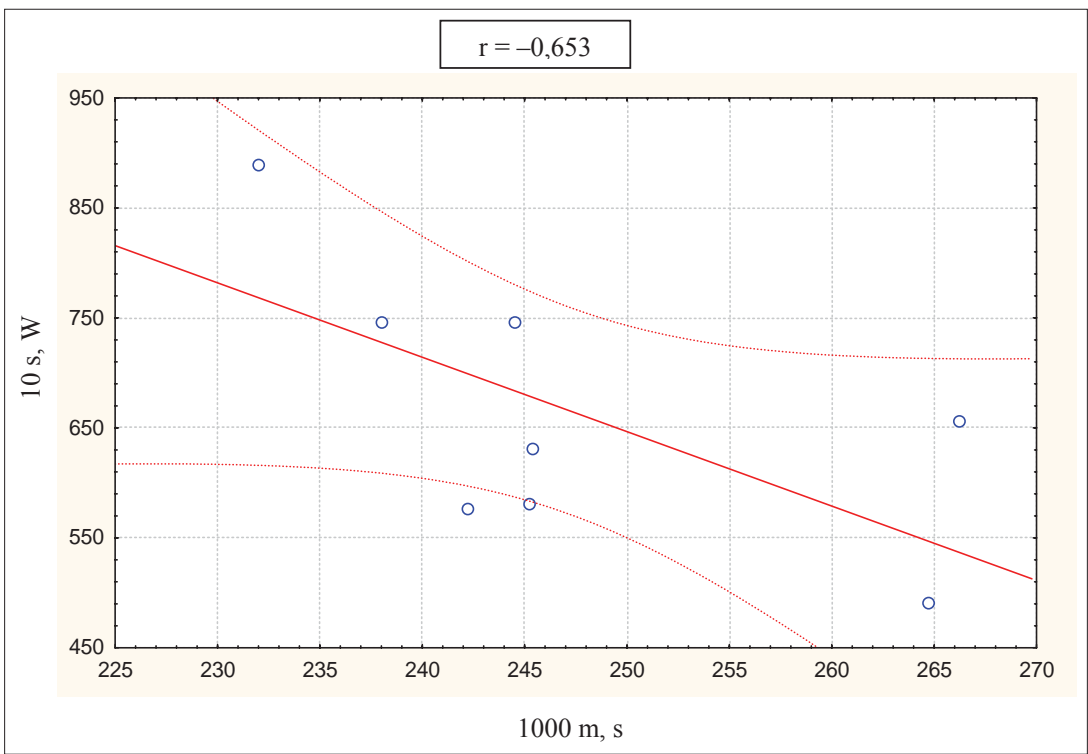

1 pav. Baidarininkų 10 s darbo galingumo ir 1000 m nuotolio iveikimo laiko koreliacinis laukas

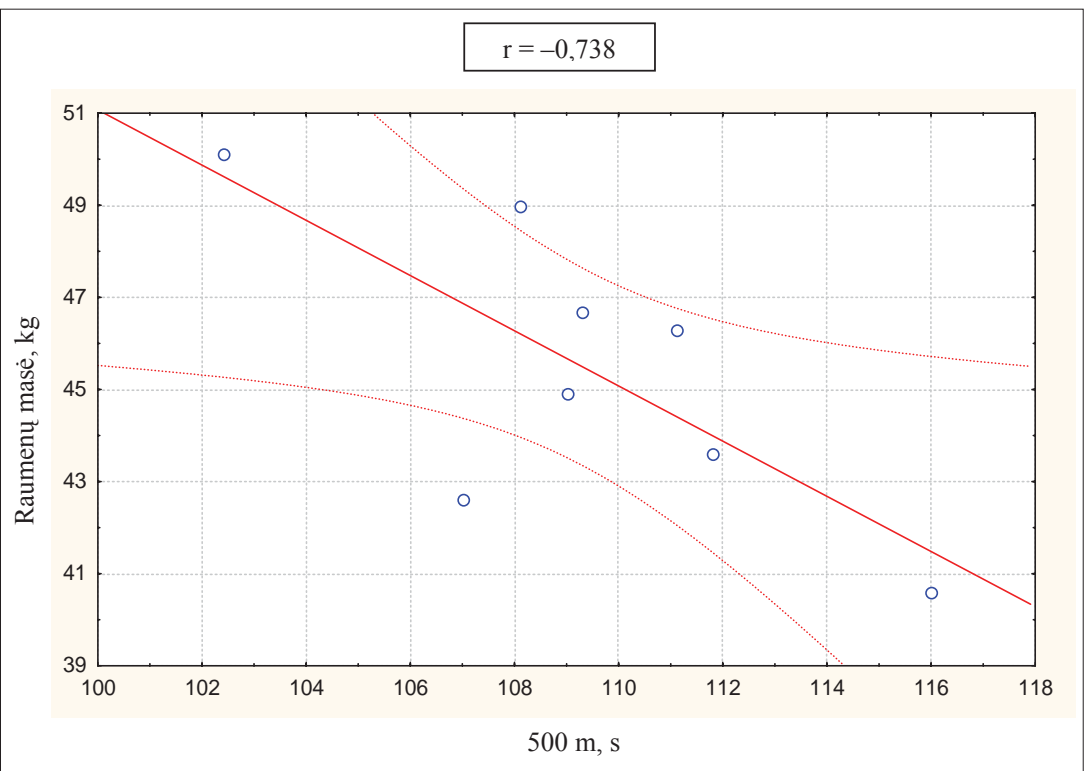

2 pav. Baidarininkų raumenų masès ir 500 m nuotolio įveikimo laiko koreliacinis laukas

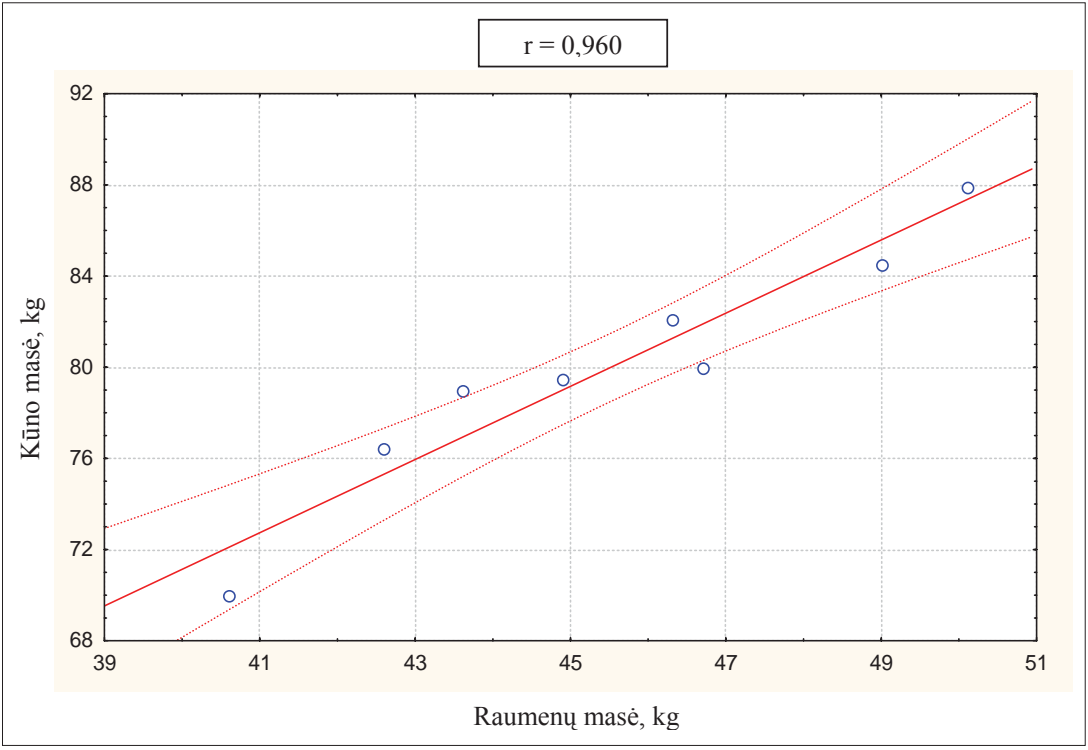

3 pav. Baidarininkų kūno masès ir raumenų masès koreliacinis laukas

tiniai ryšiai labai stiprūs $(r=-0,94$ ir $r=-0,95, \quad$ ir $r=-0,74, p<0,05)$. Visgi šių rodikliu ryšys su $\mathrm{p}<0,001)$. Nustatyta $500 \mathrm{~m}$ nuotolio įveikimo lai$1000 \mathrm{~m}$ iveikimo laiku silpnesnis. Taigi nuo rauko, kūno svorio ir raumenų masės sąsaja $(\mathrm{r}=-0,79$ menu, kaip judesiu generatorių, masès labai pri- 
4 pav. Baidarininkų $\mathbf{5 0 0}$ ir $\mathbf{1 0 0 0}$ m nuotolių iveikimo laiko koreliacinis laukas

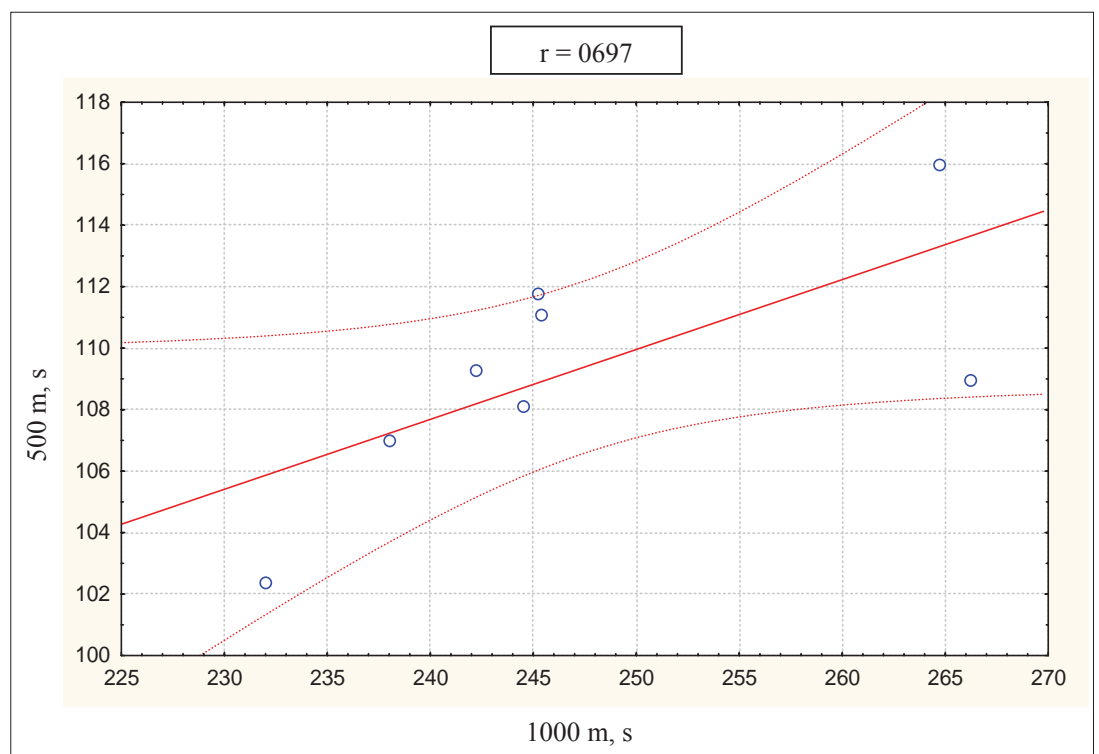

klauso 500 m nuotolio i̇veikimo rezultatas (2 pav.), bet ji mažiau susijusi su 1000 m nuotolio įveikimo laiku. Regresinè analizè rodo: padidinus raumenu masę $1 \mathrm{~kg}$ galima tikètis $500 \mathrm{~m}$ nuotolio ìveikimo laiko sumažejimo $0,74 \mathrm{~s}$. Nustatytas patikimas $500 \mathrm{~m}$ nuotolio ivveikimo laiko atvirkštinis ryšys su AARG absoliučia reikšme $(\mathrm{r}=-0,64, \mathrm{p}<0,05)$, tačiau 1000 m nuotolio i̇veikimo laiko ryšys su AARG absoliučia reikšme yra nepatikimas. Baidarininkų kūno masès rodikliai labai glaudžiai koreliuoja su raumenų mase $(\mathrm{r}=0,96, \mathrm{p}<0,001)$ (3 pav.), nes daugiau kaip 50\% jų kūno masès sudaro raumenys. Kiti tirtų baidarininkų rodikliai neturi patikimo ryšio nei su 500, nei su $1000 \mathrm{~m}$ nuotoliu ivveikimo laiku.

Atkreiptinas dèmesys į tai, kad raumenų masès rodikliai glaudžiai susiję su absoliučiu ir santykiniu AARG $(\mathrm{r}=0,92$ ir 0,70$), 10 \mathrm{~s}$ trukmès darbo specialiuoju galingumu $(\mathrm{r}=0,67, \mathrm{p}<0,05)$. Tarp 500 ir $1000 \mathrm{~m}$ nuotoliu iveikimo laiko rodikliu yra patikimas ryšys $(r=0,70)(4$ pav.).

\section{REZULTATŲ APTARIMAS}

Trys pagrindiniai varžybu nuotoliai, kuriuos iveikia baidarininkai, savo darbo trukme ir intensyvumu patenka $\mathfrak{i}$ atskiras specifines energijos gamybos zonas (Wilmore, Costill, 1994; Astrand, Rodahl, 1997; Dadelienè, 2008). Baidarininku rengimasis dalyvauti atskirų nuotolių rungtyse yra specifinis (Kahl, 1998), sportini rezultatą lemia atskiri veiksniai, jų indèlis yra skirtingas. Atlikti tyrimai (Skernevičius ir kt., 2003; Balčiūnas ir kt., 2007; Balčiūnas, 2009) parode 200 ir 500 m nuotolio ivveikimo laiko ir kai kuriu baidarininku fizinio išsivystymo, funkcinio ir fizinio pajègu- mo rodiklių sąsają. Nustatytas glaudus ryšys tarp $200 \mathrm{~m}$ nuotolio íveikimo laiko ir šuolio į aukšti rodiklio. Visgi šiuo tyrimu neaptikome patikimu ryšių tarp 500 ir 1000 m ịveikimo laiko ir šuolio i aukštị rodiklių. Visų trijų tyrimų duomenys rodo: sportinių rezultatų gerejimą, iveikiant 200, 500 ir $1000 \mathrm{~m}$ nuotolius, beveik visada lemia reikšmingas raumenų masès didejjimas. Tiriant kitų šakų sportininkus taip pat atskleista, kad raumenų mase lemia anaerobinio alaktatinio galingumo kaitą (Pečiukonienè, Dadelienè, 2003). Taigi moksliniai tyrimai irodo, kad baidarininku, kurie atlieka pagrindinius judesius irkluodami, raumenų masès didinimas yra vienas iš pagrindinių veiksnių, gerinant ne tik $200 \mathrm{~m}$ nuotolio sportini rezultata, bet ir iveikiant 500 bei $1000 \mathrm{~m}$ olimpinius nuotolius.

Ankstesni ir šie tyrimai parodè stiprius $500 \mathrm{~m}$ nuotolio iqveikimo laiko ir AARG bei $10 \mathrm{~s}$ trukmès specialiojo darbo galingumo koreliacinius ryšius. Vadinasi, anaerobinès alaktatinès energijos gamybos veiksmingumas lemia $500 \mathrm{~m}$ nuotolio íveikimo rezultatus. E. Lysenko ir kt. (Лисенко и др., 2004) nurodo, kad toks energijos gamybos būdas sudaro $17-21 \%$ visų energiniu procesų, vykstančių raumenyse. $1000 \mathrm{~m}$ ịveikimo rezultatų AARG reikšmingai nepaveike, tačiau specialusis galingumas $10 \mathrm{~s}$ trukmès darbo metu lèmè sèkmingą šio nuotolio įveikimą. Baidarininkų rengimo programose daug laiko skiriama pratimams, ugdantiems specialių raumenų masę ir galingumą (Rudzinskas ir kt., 2000; Дубровский, Жуков, 2006). Taip pat didelis demesys skiriamas baidarininkų aerobinio pajègumo ugdymui (Alekrinskis ir kt., 2005), kraujotakos ir kvėpavimo sistemos stiprinimui. Mūsų tyrimo metu nenustatyta patikimo ryšio tarp 500 ir $1000 \mathrm{~m}$ 
nuotoliu įveikimo laiko ir baidarininkų kraujotakos sistemos funkciniu rodikliu (PD gulint, RI, $\mathrm{Hb}$ koncentracijos kraujyje).

Talentingų baidarininkų atrankai skiriama daug dèmesio (Nedari, 1998; Skernevičius ir kt., 2004). Šio tyrimo duomenys, išskyrę 500 ir 1000 m nuotolių iveikimo laiko lemiamus kintamuosius, gali padèti geriau atrinkti jaunuosius baidarininkus i šią sporto šaką, o didelio meistriškumo sportininkus - orientuoti pasirinkti pagrindini nuotoli, kurį i̇veikdamas galètų siekti geriausių sportinių rezultatuc, kryptingiau planuoti ir vykdyti didelio meistriškumo baidarininkų rengimą.

Mūsų tyrimo hipotezè pasitvirtino iš dalies. Nustatyta, kad 1000 m nuotolio iqveikimo laikas patikimai koreliuoja su $10 \mathrm{~s}$ trukmès darbo specialiuoju galingumu, bet neturi patikimo ryšio su kraujotakos sistemos funkcinio pajègumo rodikliais. Kūno masė ir raumenų masè turi sąsają su $500 \mathrm{~m}$ nuotolio íveikimo laiku, o su $1000 \mathrm{~m}$ nuotolio įveikimo laiku ryšys nepatikimas.

\section{IŠVADOS}

1. Didelio meistriškumo baidarininkų $500 \mathrm{~m}$ nuotolio įveikimo rodikliai koreliuoja su jų kūno masès ir raumenų masès rodikliais, o su $1000 \mathrm{~m}$ nuotolio įveikimo laiku ryšys silpnesnis.

2. $10 \mathrm{~s}$ trukmès specialusis (tiek absoliutus, tiek santykinis) darbo galingumas turi labai stipru ryši su 500 m nuotolio įveikimo laiku, silpnesni, tačiau statistiškai patikimą $(\mathrm{p}<0,05)-$ su $1000 \mathrm{~m}$ įveikimo laiku.

3. Tirtų didelio meistriškumo baidarininkų kraujotakos rodikliai — RI, PD ramybès būsenoje, $\mathrm{Hb}$ koncentracija kraujyje - neturejo patikimo ryšio nei su 500 m, nei su 1000 m nuotolių iveikimo laiku.

\section{LITERATŪRA}

Alekrinskis, A., Stasiulis, A., Talačka, E., Pečiūnas, E. (2005). Skirtingo amžiaus ir meistriškumo baidarininkų ir kanojininku aerobinis pajëgumas. Sporto mokslas, 3 (41), $26-29$.

Astrand, P. O., Rodahl, K. (1997). Textbook of Work Physiology. New-York: McGrow. P. 584.

Balčiūnas, E. (2009). Lietuvos didelio meistriškumo baidarininkų rengimo keturmečiu olimpiniu ciklu ypatumai. Ugdymas. Kūno kultūra. Sportas, 1 (72), 12-19.

Balčiūnas, E., Pečiukonienè M., Skernevičius, J (2007). Baidarininku specialuji parengtumą sąlygojantys veiksniai. Sporto mokslas, 1 (47), 48-51.

Bosco, C., Komi, P., Tihanyj, J., Fekete, C., Apor, P. (1983). Mechanical power test and fiber composition of human leg extensor muscle. European Journal of Applied Physiology, 51, 129-135.

Byrnes, W. C., Kearney, J. T. (1997). Aerobic and anaerobic contributions during simulated canoe / kayak events. Medicine and Science in Sports and Exercise, 29 (5), $220-225$.

Dadelienè, R. (2008). Kineziologija. Vilnius: LSIC. P. 262.

Gonestas, E., Strelčiūnas, R. (2003). Taikomoji statistika. Kaunas: LKKA.

Kahl, J. (1998). Die Steurung des Ausdauertrainings mit spezifischen Stufentest (feld tests) im Kanurennsport: International Seminar on Kayak-Canoe Coatching and Science. Belgium.

Nedari, L. (1998). Performance Related Factors and Talent Identification in Junior Kayak and Canoe: International Seminar on Kayak-Canoe Coatching and Science. Belgium.

Pečiukonienè, M., Dadelienė, R. (2003). Ivairių sporto šaku sportininku fizinio parengtumo rodikliai bei ju tarpusavio ryšiai. Sporto mokslas, 1 (31), 70-74.
Raslanas, A., Skernevičius, J. (1998). Sportininku testavimas. Vilnius: LTOK.

Rudzinskas, M., Skernevičius, J., Švedas, E., Baškienė, V. (2000). Lietuvos baidarininku rengimo $2000 \mathrm{~m}$. olimpinėms žaidynėms metinio ciklo charakteristika. Sporto mokslas, 1 (19), 37-40.

Skernevičius, J., Balčiūnas, E., Rudzinskas, M., Švedas, E. (2003). Lietuvos pajègiausių baidarininkų fizinio išsivystymo, fizinio parengtumo ir funkcinio pajègumo tyrimo duomenys bei jų ryšys su specialiu galiu rodikliais. Sporto mokslas, 1 (31), 65-69.

Skernevičius, J., Dadelienė, R., Balčiūnas, E., Duonèla, A. (2004). Jaunujų baidarininkų specialiojo parengtumo statistiniai duomenys ir ju lyginamoji analizè su pasaulio čempionų rodikliais. Ugdymas. Küno kultūra. Sportas, 3 (53), $50-57$.

Skernevičius, J. (1997). Sporto treniruotès fiziologija. Vilnius.

Wilmore, J. H., Costill, D. (1994). Physiology of Sport and Exercise. Champaign: Human Kinetics.

Дубровский, А. С., Жуков, С. Е. (2006). Нормирование нагрузок силовой направленности у высококвалифицированных байдарочниц: научные труды НИИ физической культуры и спорта республики Беларусии. Минск. C. $41-45$.

Лисенко, Е., Шинкарюк, О., Самуйленко, В., Россаха, Г., Спичак, Н. (2004). Особенности функциональных возможностей гребцов на байдарках и каноэ высокой квалификации. Наука в олимпийском спорте, 2, 65-71.

Шеррер, Ж. (1973). Физиология труда. Москва. 


\title{
DETERMINANT FACTORS FOR INDICES OF HIGH PERFORMANCE CANOEISTS COVERING OLYMPIC DISTANCES
}

\author{
Egidijus Balčiūnas, Juozas Skernevičius, Kazys Milašius \\ Vilnius Pedagogical University, Vilnius, Lithuania
}

\begin{abstract}
The aim of the research was to analyse sport result correlation of high performance canoeists $1000 \mathrm{~m}$ distance rowing with their physical development data and the functional indices of physical power, working power of various duration and the circulatory system.

Eight Lithuanian national team candidates were analysed according to the programme "London-2012" at the end of the preparatory period of 2008. The main physical development indices of height, body mass, body fat, right and left hand power, and vital lung capacity were measured (Dadelienė, 2008). Jump height, while taking off with both legs and swinging with both hands, absolute and relative single muscular contraction power (SMCP) (Bosco et al., 1983), anaerobic alactic muscular power (AAMP) (step ergometry) were measured aiming to analyse their physical fitness. Special anaerobic alactic power was estimated by working on canoe ergometer for 10 seconds. 500 and $1000 \mathrm{~m}$ simulation tests were performed on the same canoe ergometer with individually applied special programme that corresponded to athlete's body mass. Heart rate (HR) — b / min while lying, Roufier index (RI) (Weppep, 1973), and blood haemoglobin (Hb) concentration were established aiming to evaluate the functional capacity of the circulatory system.

The methods of mathematical statistics were applied for the analysis of the research data. Linear correlation (Pierson's) coefficient calculation method was applied to estimate the indices of correlation (Gonestas, Strielčiūnas, 2003).

The research revealed that the indices of high performance canoeists $500 \mathrm{~m}$ distance rowing correlated with athletes body and muscle mass indices; the smaller correlation was between those indices and the timespan of $1000 \mathrm{~m}$ rowing.

The special (both absolute and relative) 10-s duration working power highly correlated with the timespan of $500 \mathrm{~m}$ rowing and the lower statistically reliable $(\mathrm{p}<0.05)$ correlation was found with $1000 \mathrm{~m}$ rowing time-span.

High performance canoeists bloodstream indices - RI, PR in rest, Hb blood concentration - did not have any reliable correlation with 500 and $1000 \mathrm{~m}$ distances rowing time-span.
\end{abstract}

Keywords: physical development of canoeists, physical fitness, bloodstream, correlation links.

Egidijus Balčiūnas

Vilniaus pedagoginis universitetas

(Vilnius Pedagogical University)

Studentu g. 39, LT-08106 Vilnius

Lietuva (Lithuania)

Tel +37068680630

E-mail balciunas@bki.lt 